\title{
Identification of acrosin in mouse spermatozoa
}

\author{
C. R. Brown and E. F. Hartree \\ A.R.C. Unit of Reproductive Physiology and Biochemistry, University of Cambridge, U.K.*
}

The gelatin-film test for neutral proteinase activity (Gaddum \& Blandau, 1970) has been applied to rodent spermatozoa in several laboratories (for details see Brown \& Hartree, 1976). There is general agreement that activities are low in rat and mouse spermatozoa. More recently Erickson \& Martin (1974) have concluded that the neutral proteinase in mouse spermatozoa is not acrosin. They used a sensitive trypsin assay based on the release of $\left[{ }^{3} \mathrm{H}\right]$ methanol from tosylarginine $\left[{ }^{3} \mathrm{H}\right]$ methyl ester and found that the very low hydrolytic activities in fractions from mouse spermatozoa were not decreased by inhibitors of acrosin. As far as we are aware this is the first report of failure to detect acrosin in mammalian spermatozoa. Since this finding is contrary to our experience we are giving evidence for the presence of acrosin in mouse spermatozoa.

\section{Fractionation of spermatozoa}

Epididymides were excised from 10 Carworth Europe CFLP mice (non-inbred, aged about 9 months) and sliced with a scalpel under sucrose solution $(0.25 \mathrm{M})$. The suspension was strained through several layers of cheesecloth to remove tissue debris and acrosin was extracted from the spermatozoa according to the method outlined in Flow-sheet 1 . The denudation process has been described by Brown, Andani \& Hartree (1975), and involved freeze-thawing, vortex-mixing for $30 \mathrm{sec}$, centrifuging at $1000 \mathrm{~g}$ (to obtain the 'denudation supernatant'), washing the sedimented spermatozoa with $0.25 \mathrm{M}$-sucrose, and suspending them in sucrose to $1.5 \mathrm{ml}$. The wash-fluids that

Flow-sheet 1. Outline of the method used to obtain acrosin from mouse spermatozoa. The Fraction $\mathbf{B}^{\prime}$ used in some experiments was prepared by a modification of the above procedure (see text).

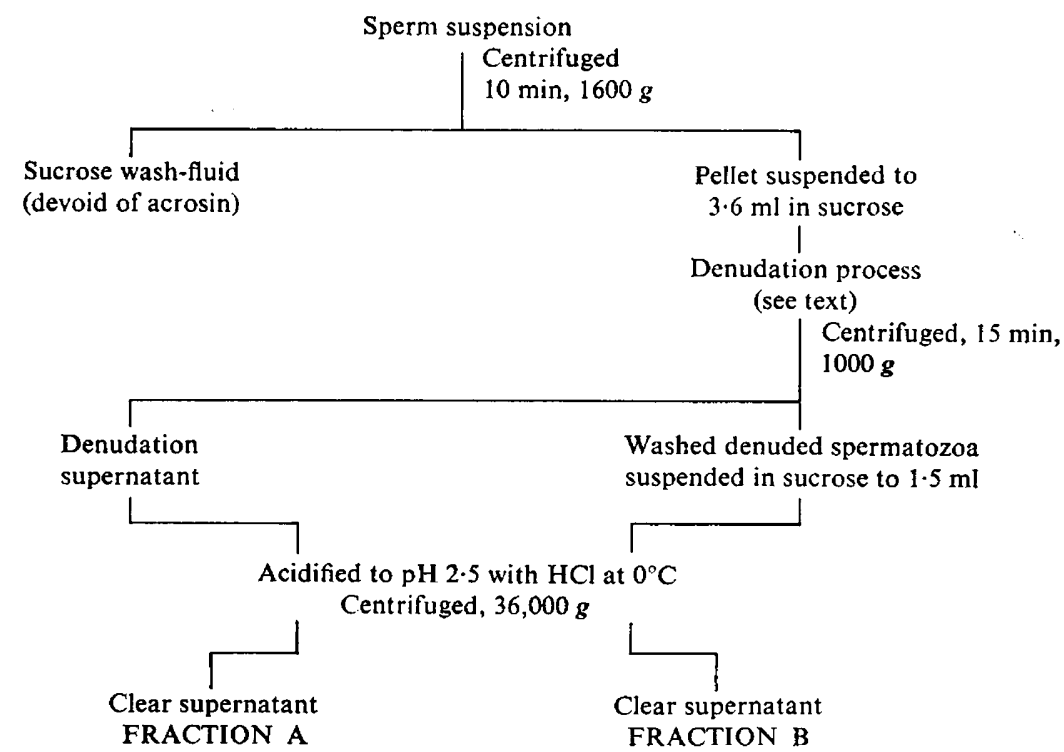

- Postal address: Animal Research Station, 307 Huntingdon Road, Cambridge CB3 0JQ, U.K. 
were discarded in this process were devoid of acrosin. The two acrosin-containing fractions (Flowsheet 1) were acidified (Brown et al., 1975) to recover acrosin in soluble form (Fractions A and B). The acrosin in these acid extracts was very stable at $5^{\circ} \mathrm{C}$.

A second suspension of spermatozoa (from 20 mice) was similarly fractionated except that the cells were exposed to greater physical stress by being frozen-thawed twice and vortex-mixed for $60 \mathrm{sec}$. After this treatment the denudation supernatant was devoid of acrosin and the entire complement of enzyme was recovered in Fraction B' (which corresponds to Fraction B in Flow-sheet 1). Attempts to liberate acrosin from spermatozoa by further vortex mixing were unsuccessful. The presence of acrosin-containing particles only in the denudation supernatant of the first fractionation, i.e. after the milder disintegrative treatment, suggests that such particles can become re-associated with the sperm cells when physical stress is prolonged. On the other hand, the differing results could have arisen from the different cell densities of the original suspensions.

\section{Acrosin assays: materials and methods}

Soya-bean trypsin inhibitor, $p$-aminobenzamidine, dimethyl sulphoxide $\left(\mathrm{Me}_{2} \mathrm{SO}\right)$, benzoylarginine ethyl ester (BAEE), benzoylarginine-2-naphthylamide (BANA) and ram acrosomal acrosin inhibitor, were those used by Brown et al. (1975). Hydrolysis of BAEE was followed at $25^{\circ} \mathrm{C}$ in 50 mM-tris- $\mathrm{HCl}-0 \cdot 2 \mathrm{M}-\mathrm{CaCl}_{2}, \mathrm{pH} \mathrm{8 \cdot 2}$. The procedure for 'total' activity (Brown et al., 1975) was followed. Hydrolysis of BANA by mouse Fraction $\mathrm{B}^{\prime}$ was measured at $37^{\circ} \mathrm{C}$ in an Aminco-Bowman Spectrophotofluorimeter. The experimental conditions were: (i) excitation $337 \mathrm{~nm}$, emission $427 \mathrm{~nm}$; (ii) sensitivity $=3$; (iii) $10 \times 10 \mathrm{~mm}$ cuvettes; (iv) external recorder set at $5 \mathrm{mV}$ full scale. Unless otherwise stated, the fluorimetry buffer contained 50 mM-tris, $0.2 \mathrm{M}-\mathrm{CaCl}_{2}, 10 \%(\mathrm{v} / \mathrm{v}) \mathrm{Me}_{2} \mathrm{SO}$ and $\mathrm{HCl}$ to pH 8.2. Buffered BANA was 4 vol of fluorimetry buffer plus 1 vol of 10 mM-BANA in $\mathrm{Me}_{2} \mathrm{SO}$; BANA is kept in solution by $\mathrm{Me}_{2} \mathrm{SO}$ which prevents precipitation when Fraction $\mathrm{B}^{\prime}$ is brought to pH 8.2 (Brown et al., 1975). To follow the hydrolysis of BANA, $50 \mu \mathrm{l}$ Fraction B' (plus inhibitor where specified) was diluted to $0.5 \mathrm{ml}$ with fiuorimetry buffer and after $5 \mathrm{~min}$ at $37^{\circ} \mathrm{C} 0.5 \mathrm{ml}$ buffered BANA was added. The increase of fluorescence was followed for $5 \mathrm{~min}$. The recorder was calibrated by adding known quantities of 2-naphthylamine to a mixture $(1: 1)$ of fluorimetry buffer and buffered BANA. Full-scale deflection was obtained with $0.7 \mathrm{nmol}$ naphthylamine. Fluorimetric assays were also performed in buffers covering the $\mathrm{pH}$ range $6 \cdot 0-8.8$. Each buffer contained $50 \mathrm{~mm}$-tris, $50 \mathrm{~mm}$ 2(N-morpholino)ethanesulphonic acid (Hopkin \& Williams Ltd, P.O. Box 1, Romford RM1 1HA), $0 \cdot 2 \mathrm{M}-\mathrm{CaCl}_{2}, 10 \%(\mathrm{v} / \mathrm{v}) \mathrm{Me}_{2} \mathrm{SO}$ and either $\mathrm{NaOH}$ or $\mathrm{HCl}$ to give the required $\mathrm{pH}$. Cuvettes received $0.9 \mathrm{ml}$ buffer, $50 \mu \mathrm{l}$ of the above $10 \mathrm{~mm}$-BANA and finally $50 \mu \mathrm{l}$ Fraction $\mathrm{B}^{\prime}$.

\section{Results and conclusions}

Acrosin activities of fresh $0.5 \mathrm{ml}$ portions of Fractions A and B were, respectively, 88 and 100 nmol BAEE hydrolysed/min. From these values we calculate that the total acrosin extractable from $10^{7}$ mouse spermatozoa would hydrolyse $56 \mathrm{nmol} \mathrm{BAEE} / \mathrm{min}$, i.e. about $20 \%$ of the level customarily observed in denuded ram spermatozoa (Brown \& Hartree, 1974; Brown et al., 1975). The requirement for $0.5 \mathrm{ml}$ enzyme fraction ruled out further assays with BAEE and the fluorimetric assay was used for subsequent experiments.

Fresh Fraction $\mathbf{B}^{\prime}$ actively hydrolysed BANA and showed the customary sensitivity to inhibitors of acrosin (Table 1). However, after it had been stored for 16 days at $5^{\circ} \mathrm{C}$ it became very unstable if adjusted to $\mathrm{pH} 8 \cdot 2$. Consequently, when it was assayed as in Table 1 (control), i.e. with prior incubation of enzyme and buffer (pH 8.2), it showed no activity. If the stored Fraction B' $^{\prime}$ was assayed by adding it directly to fluorimetry buffer plus BANA initial activity was $40 \%$ higher than that shown in Table 1 but the rate of hydrolysis, unlike that observed with fresh Fraction $\mathbf{B}^{\prime}$, decreased rapidly during $5 \mathrm{~min}$. A similarly unstable rabbit acrosin has been described (Zaneveld, Polakoski \& Williams, 1972). When hydrolysis of BANA by fresh Fraction $B^{\prime}$ was measured at different pH values, the relative rates were 79 at $\mathrm{pH} 8 \cdot 8,100$ at $\mathrm{pH} 8 \cdot 2,56$ at $\mathrm{pH} 7 \cdot 0$ and 14.5 at $\mathrm{pH} 6.0$. We have obtained a similar activity/pH profile for ram acrosin. 
Table 1. Effect of inhibitors of acrosin on the hydrolysis, at pH 8.2, of BANA by an acid extract $\left(50 \mu 1\right.$ Fraction $\left.\mathrm{B}^{\prime}\right)$ of mouse spermatozoa

Inhibitors

pmol BANA hydrolysed $/ \mathrm{min} / 10^{7}$

spermatozoa

\begin{tabular}{lr}
\hline (control) & 152 \\
Soya-bean trypsin inhibitor $(5 \mu \mathrm{g})$ & 70 \\
Soya-bean trypsin inhibitor $(10 \mu \mathrm{g})$ & 35 \\
Soya-bean trypsin inhibitor $(40 \mu \mathrm{g})$ & 16 \\
Acrosomal acrosin inhibitor $(4 \mu \mathrm{g})$ & 60 \\
Acrosomal acrosin inhibitor $(10 \mu \mathrm{g})$ & 39 \\
p-Aminobenzamidine $(0.1 \mathrm{mM})$ & 11 \\
p-Aminobenzamidine $(0.5 \mathrm{mM})$ & 0 \\
p-Aminobenzamidine $(2.5 \mathrm{~mm})$ & 0
\end{tabular}

The assays were fluorimetric and they involved prior incubation of enzyme and inhibitor (see text). Inhibitor concentrations are those present after dilution of enzyme to $1 \mathrm{ml}$ with BANA solution.

* This is about $8 \%$ of the activity shown by acid extracts of ram spermatozoa (Brown et al., 1975).

$\dagger$ From ram spermatozoa (see text).

Our experiments provide acceptable evidence that mouse spermatozoa contain acrosin and also that the failure of Erickson \& Martin (1974) to detect this proteinase arose either from a failure to extract it from mouse spermatozoa or from its extraction in an unstable form. These authors used two extraction procedures: (i) sonication of an aqueous suspension, and (ii) extraction with $1 \mathrm{M}$ acetic acid. When ram spermatozoa are treated by the first method no acrosin is solubilized and the acrosin activity of the suspension decreases with time of sonication, i.e. the enzyme is unstable. Application of the second method to ram spermatozoa solubilizes only about $25 \%$ of the activity that can be solubilized at $\mathrm{pH} 2.7$ by the method of Brown et al. (1975). We conclude that neither extraction procedure is suitable for obtaining acceptable yields of mouse acrosin. Methods for extraction of acrosin which have been developed for one species are not necessarily appropriate for other species (Brown \& Hartree, 1976). In our view the most reliable methods for disrupting spermatozoa without loss of acrosin activity are those in which the suspending medium is $0.25 \mathrm{M}$-sucrose (Brown et al., 1975; Brown \& Hartree, 1974, 1976).

The widespread occurrence of acrosin in spermatozoa, together with the fact that it is only known to occur in the acrosome, lend credence to the view that it plays an important role in the interaction of spermatozoon and egg.

\section{References}

Brown, C.R. \& HARTreE, E.F. (1974) Distribution of a trypsin-like proteinase in the ram spermatozoon. J. Reprod. Fert. 36, 195-198.

Brown, C.R. \& Hartree, E.F. (1976) Comparison of neutral proteinase activities in cock and ram spermatozoa and observations on a proacrosin in cock spermatozoa. J. Reprod. Fert. 46, 155-164.

Brown, C.R., ANDANI, Z. \& HaRTree, E.F. (1975) Studies on ram acrosin. Isolation from spermatozoa, activation by cations and organic solvents, and influence of cations on its reaction with inhibitors.
Biochem. J. 149, 133-146.

ERICKSON, R.P. \& MARTIN, S.R. (1974) Demonstration of the lack of acrosin in mouse spermatozoa by a radioassay. Contraception $9,359-365$.

Gaddum, P. \& Blandau, R.J. (1970) Proteolytic reaction of mammalian spermatozoa on gelatin membranes. Science, N.Y. 170, 749-751.

ZaNeVeld, L.J.D., Polakoski, K.L. \& Williams, W.L. (1972) Properties of a proteolytic enzyme from rabbit sperm acrosomes. Biol. Reprod. 6, 30-39. 